Neurosurg Focus 6 (1):Article 1, 1999

\title{
An evidence-based review of surgical decompression for acute spinal cord injury: rationale, indications, and timing based on experimental and clinical studies
}

\author{
Michael G. Fehlings, M.D., Ph.D., and Charles H. Tator, M.D., Ph.D. \\ Division of Neurosurgery and Spinal Program, Toronto Hospital and University of Toronto, Toronto, \\ Ontario, Canada
}

The authors conducted an evidence-based review of the literature to evaluate critically the rationale and indications for and the timing of decompressive surgery for the treatment of acute, nonpenetrating spinal cord injury (SCI).

The experimental and clinical literature concerning the role of, and the biological rationale for surgical decompression for acute SCI was reviewed. Clinical studies of nonoperative management of SCI were also examined for comparative purposes. Evidence from clinical trials was categorized as Class I (well-conducted randomized prospective trials), Class II (well-designed comparative clinical studies), or Class III (retrospective studies).

Studies in which animal models of SCI were used consistently demonstrated a beneficial effect of early surgical decompression, although it is difficult to apply these data directly to the clinical setting. The clinical studies provided suggestive (Class III and limited Class II) evidence that decompressive procedures improve neurological recovery after SCI. However, no clear consensus can be inferred from the literature as to the optimum timing of decompressive surgery. Many authors have advocated delayed treatment to avoid medical complications, although there is good evidence from recent Class II trials that early decompressive surgery can be performed safely without added morbidity or mortality.

There is biological evidence from experimental studies in animals that early surgical decompression may improve neurological recovery after SCI, although the relevant interventional timing in humans remains unclear. To date, the role of surgical decompression in patients with SCI is only supported by Class III and limited Class II evidence. Accordingly, decompressive surgery for SCI can only be considered a practice option. Furthermore, analysis of the literature does not allow definite conclusions to be drawn regarding appropriate timing of intervention. Hence, there is a need to conduct well-designed experimental and clinical studies of the timing and neurological results of surgical decompression for the treatment of acute SCI.

Key Words * surgical decompression * acute spinal cord injury * review

With an average incidence of 11,000 cases per year in North America, spinal cord injury (SCI) is an important cause of morbidity and mortality,[63,91] particularly among teenagers and young adults. The main 
causes of acute SCI are traffic accidents, sports and recreational activities, accidents at work, falls in the home, and violence,[63,91] Because there is a lack of effective treatments for restoring neurological function below the level of the injury means the vast majority of SCI victims face many years of lost independence and continued medical expenses. Indeed, the financial cost of care for acute SCI is enormous.[97] For example, in 1975, Kraus, et al.,[63] estimated an "annual cost to the United States for support and treatment of all persons with a spinal cord injury of two billion dollars," and in 1990, Stripling[86] estimated that this figure had risen to four billion dollars annually.

The results of recent studies of pharmacotherapy, such as the use of methylprednisolone as recommended on the basis of the National Acute Spinal Cord Injury Studies (NASCIS-2 and NASCIS-3)[21-23] have shown improved recovery in patients with SCI. Unfortunately, the improved neurological recovery observed to date has been modest, with only slight improvement in the functional capability in these patients.

Recent advances in the safety and efficacy of spinal cord surgical decompressive procedures offer significant potential for repairing some of the neurological damage caused by injuries to the spine. $[4,14,33,96,110]$ Despite the widespread use of surgery in patients with acute SCI in North America, the role of this intervention in improving neurological recovery remains controversial because of the lack of well-designed and -executed randomized controlled trials. In the present paper, we review the experimental and clinical evidence with regard to the value of surgical decompression in treating patients with acute nonpenetrating SCI and compare these data with the results of conservative, nonoperative management of SCI. This evidence-based literature analysis was conducted as part of the Surgical Trial in the Acute Spinal Cord Injury Study project, an undertaking supported by the Joint Section of Neurotrauma and Critical Care and the Joint Section of Disorders of the Spine and Peripheral Nerves of the American Association of Neurological Surgeons and the Congress of Neurological Surgeons. The goal of the Surgical Trial in Acute Spinal Cord Injury Study is ultimately to plan and conduct a randomized controlled trial to investigate the appropriate timing and clinical indications for decompressive surgery in the injured spinal cord.

\section{CLINICAL MATERIAL AND METHODS}

We conducted a computer-assisted Medline search of the experimental and clinical literature from 1966 to 1998 that concerned the role of decompressive surgery in the treatment of SCI. Only articles with English-language abstracts were selected for review. This computerized literature review was supplemented by a detailed examination of the reference lists from the selected articles. Fifty-nine papers (16 experimental studies in animal models and 43 clinical studies) were selected for detailed analysis (Tables 1-5). Evidence from clinical trials was classified as Class I (well-designed and -conducted randomized controlled trials), Class II (prospective cohort studies or controlled studies with well-defined comparison groups) and Class III (case series, retrospective reviews, and expert opinion).

\section{BIOLOGICAL RATIONALE FOR EARLY TREATMENT OF PATIENTS WITH ACUTE SCI}

\section{Concept of Secondary Injury}

There is increasing evidence that the pathophysiology of acute SCI involves both primary and secondary injury mechanisms, $[6,56,92,93,99,106,114,115]$ In the majority of traumatic SCIs, the mechanism of injury involves rapid cord compression due to bone displacement from a fracture-dislocation or burst fracture.[27,58,95] Acute spinal cord distraction, acceleration-deceleration with shearing, and transection from penetrating injuries are other potential mechanisms of injury. $[39,63]$ There is considerable evidence that the primary mechanical injury initiates a cascade of secondary injury mechanisms such as: 1) vascular changes including reduction in blood flow, loss of autoregulation, neurogenic shock, hemorrhage, loss of microcirculation, vasospasm and thrombosis (see Stripling[86] and Tator[94] for reviews); 2) electrolyte 
shifts including increased intracellular calcium, increased extracellular potassium, and increased sodium permeability;[2,117] 3) neurotransmitter accumulation such as serotonin or catecholamines[77] and extracellular glutamate,[3] the latter producing excitotoxicity;[46] 4) arachidonic acid release, free radical production especially oxygen-free radicals,[37] eicosanoid production, especially prostaglandins, and lipid peroxidation;[54,56] 5) endogenous opioids;[44,45] 6) edema formation;[105] 7) inflammation;[142] and 8) loss of energy metabolism, especially decreased adenosine triphosphate production.[8] These theories of secondary injury have been the subject of several recent reviews.[7,30,43,99,116]

The improved understanding of the pathophysiology of acute SCI has led to use of novel pharmacological strategies to attenuate the effects of the secondary injury. In the NASCIS-2 study a modest beneficial effect of high-dose methylprednisolone was demonstrated if given within 8 hours postinjury in patients with complete and incomplete SCIs,[22] which emphasizes the importance of the timing of treatment.

Furthermore, the NASCIS-3 study provided some evidence that treatment within 3 hours may have been superior to treatment begun between 3 and 8 hours postinjury.[23] The findings of these studies provide validity to the concept that secondary SCI mechanisms can be attenuated in the clinical setting. It is unclear, however, whether the "time window" for methylprednisolone is directly applicable to surgical decompression of the spinal cord.

There is experimental evidence that persistent compression of the spinal cord is a potentially reversible form of secondary injury. The severity of SCI in experimental models appears to vary depending on several factors, including force of compression, duration of compression, displacement, impulse and kinetic energy.[39,50,57,75,78,80,89] The evolution of these pathophysiological processes leading to progressive pathological changes during the first few hours postinjury is important with respect to the surgical and nonsurgical treatment of SCI. As we will describe in the following detail, the severity of the pathological changes and the degree of recovery are directly related to the duration of acute compression as demonstrated by experimental studies in which longer compression times produced less demonstrable clinical recovery.[21,36,39,50,76,87]

\section{Studies of Surgical Decompression in Experimental Models}

Biomechanics of spinal cord injury and classification of models. Several experimental studies of decompressive procedures performed after SCI have been conducted using these models,[16,25,29,34,36,39,50,61,62,76,87,88,90] and most have demonstrated that neurological recovery is enhanced by early decompressive surgery (Table 1 ). 
TABLE 1

EFFECT OF DECOMPRESSION IN ANMAL MODELS OF ACUTE SCI

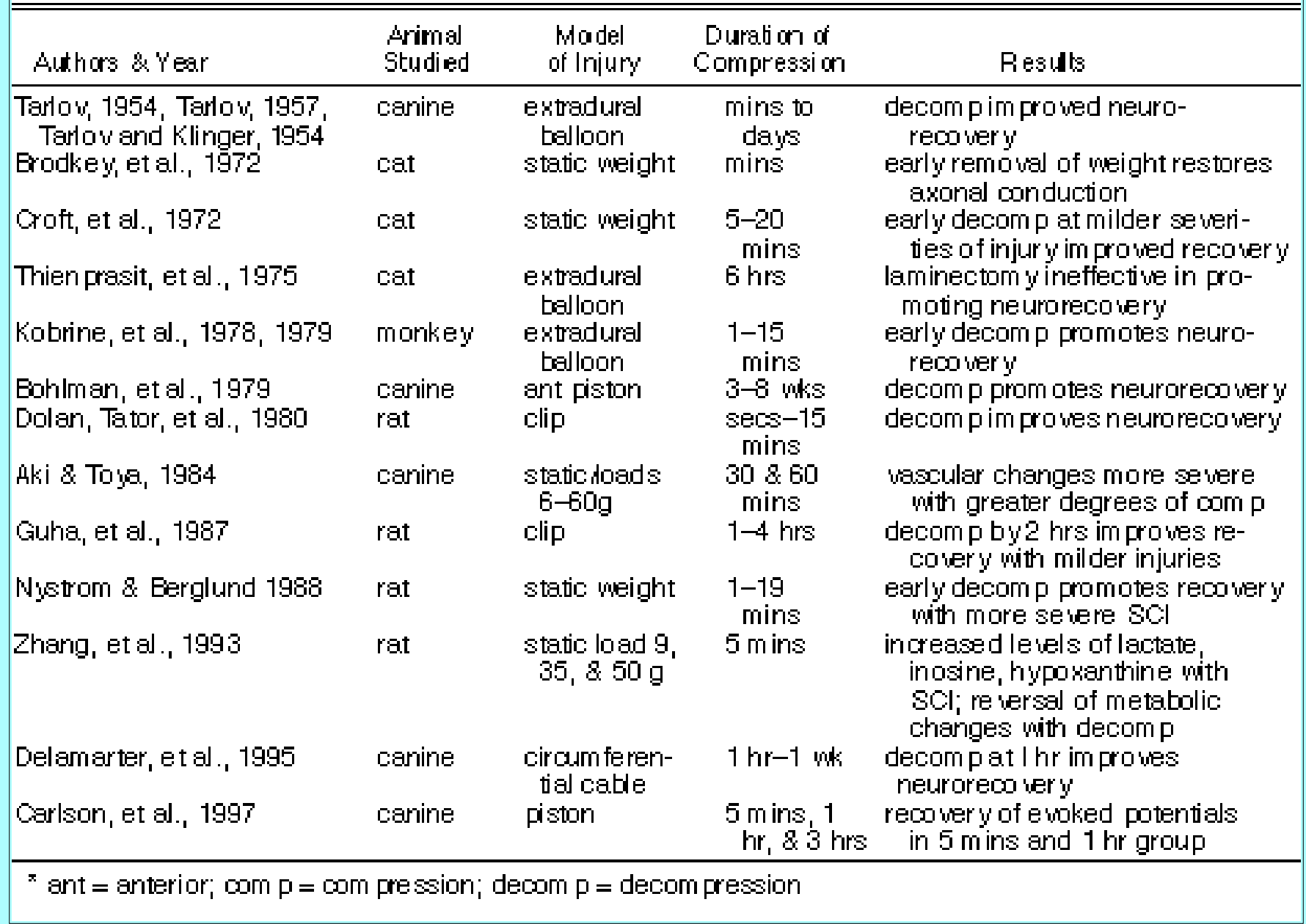

However, to understand the rationale of spinal cord decompressive surgery in the context of acute SCI and to interpret the results of experimental studies correctly, a brief review of the biomechanics of SCI and the relevant experimental models is appropriate. The spinal cord is viscoelastic and behaves as a linear elastic material under small strains (strain $=$ force/area).[57] Indeed, Somerson and Stokes[83] have shown in compression injuries causing less than $1.0 \mathrm{~mm}$ deformation of the rodent spinal cord that the cord behaves like a spring, with a linear relationship between the applied force and the resultant displacement. In contrast, at displacements greater than $1.0 \mathrm{~mm}$, the spinal cord displays nonlinear characteristics. Consequently, the relationship between the degree of spinal cord displacement from a space-occupying lesion and the loss of neurological function may also be nonlinear. Nevertheless, clinical outcome and morphometric characteristics of the spinal cord lesion do appear to vary depending on a number of factors, including force, duration of compression, displacement, impulse, and kinetic energy.[39,50,57,75,78,80]

In one review we found that several experimental models have been developed that mimic human SCI.[47] Compression models can be classified as either kinetic or static according to the biomechanics of the applied forces. Kinetic compression models involve rapid compression of the cord in less than 1 second. Indeed, most kinetic models compress the cord in less than 100 milliseconds. With kinetic compression, the applied load compresses the cord with increasing velocity (acceleration $>0$ ) to the point of maximal cord compression. In contrast, static compression models use forces that slowly compress the cord at approximately constant velocity.

Kinetic Models of Spinal Cord Injury. Of the many types of kinetic compression models, which most closely simulate the majority of traumatic human SCIs, the studies that relate the duration of compression to 
the recovery of function have been limited to the extradural balloon compression technique in several species and the clip compression model in rodents. The advantage of the latter technique is that the force of clip closure can be calibrated precisely, and the duration of the compression can be altered over a wide range of times.

Tarlov and Klinger[87,88,90] have used the extradural balloon compression technique to injure the lumbar spinal cord and cauda equina in dogs. With acute SCI, the degree of recovery varied with the size of the balloon ("medium" or "large") and with the duration of compression. For example, with a large-sized balloon, full recovery was seen with decompressive surgery after 1 minute, partial recovery was seen after 5 minutes, and no recovery was demonstrated if compression was maintained longer. With medium-sized balloons, recovery was seen if decompressive surgery was performed within 1 hour of injury. The shortcomings of this study were the variable placement of the balloon and the lack of precise quantitation of the injury force or balloon pressure.

Kobrine and colleagues[61,62] conducted a series of experiments in monkeys in which spinal cord compression at the T-6 level was produced by an inflatable extradural balloon. In the slow balloon inflation group, there was return of function based on return of the spinal cord evoked potential even after periods of compression that lasted several minutes.[61] However, after rapid balloon inflation and acute spinal cord compression, only the animals that underwent compression for 1 minute had return of the response by 1 hour. In contrast, animals that underwent acute compression for 3, 5, 7, or 15 minutes showed no recovery by 1 hour.[62] No recordings were obtained after 1 hour, and thus it is not known if some recovery would have occurred after that timepoint. The authors concluded that recovery of spinal cord function following spinal cord compression depended on the "rapidity and length of time of compression."[62] Thus, with an extradural balloon compression method in dogs and cats, the duration of compression was found to be a significant determinant of neurological recovery but only when decompression was performed after a period of minutes.

In the laboratory of one of the authors (C.H.T.), Dolan, et al.,[39] used an extradural clip compression model of the $\mathrm{T}-1$ cord in rats to provide a more quantitative assessment of injury force. The springs of modified aneurysm clips were machined to provide closing forces of 16,71 , or $178 \mathrm{~g}$. Durations of compression times between 3 and 900 seconds were examined. We found that clinical neurological recovery, as assessed by the inclined plane technique,[81] varied exponentially according to the force of injury and linearly with the duration of compression. The results of this study demonstrated that the major determinant of recovery was the initial force of injury. However, the duration of compression (and thus time to decompressive intervention) was a significant determinant of clinical recovery, even in cases of severe injury forces. The main shortcoming of this study was that the maximum duration of compression examined (900 seconds) was too short to be of clinical relevance. Subsequently, our laboratory extended the duration of compression to 4 hours in the study reported by Guha, et al.,[50] with injury forces of 2.3, 16.9, or $53.0 \mathrm{~g}$ and durations of compression of 15, 60, 120, or 240 minutes. Again, the major determinant of recovery was the force of injury, although the time to decompression also affected clinical recovery. The beneficial effects of early decompressive surgery were most apparent in the groups receiving smaller-force injuries (2.3 and $16.9 \mathrm{~g})$. For example, decompression performed at 2 hours produced significantly more recovery than when performed at 4 hours.

In conclusion, the results of these studies confirm the efficacy of surgical decompressive procedures in attenuating the deleterious effects of acute SCI. However, it is difficult to extrapolate the results of these studies to clinical practice. Intuitively, it appears likely that the time window in humans is much longer than in the species studied experimentally. 
Static Models of Spinal Cord Injury. Static models, which involve a gradual compression of the spinal cord, are useful to model the effect of spinal cord displacement, as well as strain and duration of compression. However, because the load is applied slowly to the cord, these models do not accurately simulate the biomechanical aspects of the majority of human SCI. Nystrom and Berglund[76] have used a static model of SCI in rats to examine the role of injury force and duration of compression on clinical neurological recovery. Weights of 20,35, or $50 \mathrm{~g}$ were applied to the midthoracic cord of rats for periods of 1,5 , or 19 minutes, and clinical neurological recovery was assessed by using the inclined plane technique.[81] In the 20-g injury group, the duration of compression was not a significant determinant of neurological recovery. However, when the 35- and 50-g weights were applied, neurological recovery varied directly according to the duration of the compression period. Unfortunately, the durations of compression studied were too brief to be clinically meaningful, although the results suggest that the timing of decompressive intervention may play a significant role in outcome after acute SCI. Tarlov[88] also examined the role of decompressive surgery in a model of gradual extradural balloon inflation. Functional recovery varied both as a function of injury "force" (determined by the size of the balloon) and duration of compression. For example, if the extradural balloon was inflated over 75 minutes to the point of paralysis, excellent neurological recovery was attained if deflation was performed within 9 hours. In contrast, if the period of balloon inflation was extended to 48 hours, full neurological recovery was seen if decompression was performed within 7 days.

\section{CLINICAL STUDIES}

\section{Role of Conservative Management in Acute Spinal Cord Injury}

To evaluate the possible role of surgery in the management of SCI, it is important, for comparative purposes, to examine the results of conservative, nonoperative treatment (Table 2).

\begin{tabular}{|c|c|c|c|c|}
\hline \multicolumn{5}{|c|}{ TABLE 2} \\
\hline Authors \& Year & $\begin{array}{l}\text { No. of Patierts } \\
\text { (level treated) }\end{array}$ & Study Desi gn & $\begin{array}{l}\text { Class } \\
\text { of Evi- } \\
\text { dence }\end{array}$ & Resuls \\
\hline Guttman, 1963 & $\begin{array}{l}396 \text { (all le wels) } \\
\text { nonop }\end{array}$ & $\begin{array}{l}\text { retro case } \\
\text { series }\end{array}$ & III & $\begin{array}{l}30 \text { died; } 3 \text { neurologically worse; } \\
120 \text { im prowed }>1 \text { grade }\end{array}$ \\
\hline $\begin{array}{l}\text { Frankel, et al., } \\
1969\end{array}$ & $\begin{array}{l}612 \text { (all le vels) } \\
\text { nonop }\end{array}$ & $\begin{array}{l}\text { retro case } \\
\text { series }\end{array}$ & III & $\begin{array}{l}\text { onl y } 4,612 \text { de veloped delayed in- } \\
\text { stability; } 29 \% \text { of Frankel in pts } \\
\text { im pro ved }>1 \text { grade }\end{array}$ \\
\hline $\begin{array}{l}\text { Maynard, et al., } \\
1979\end{array}$ & $\begin{array}{l}123 \text { (cervical) } \\
57 \text { nonop }\end{array}$ & $\begin{array}{l}\text { retro case } \\
\text { series }\end{array}$ & III & $\begin{array}{l}\text { nonop shomed similar results to } \\
\text { surgical treatment }\end{array}$ \\
\hline Harris, et al., 1980 & $\begin{array}{l}145 \text { (cervical) } \\
48 \text { op, } 97 \\
\text { nonop }\end{array}$ & $\begin{array}{l}\text { retro case } \\
\text { series }\end{array}$ & III & $\begin{array}{l}\text { neither surgery nor realignment of } \\
\text { spinal column im prowed neuro } \\
\text { outcome }\end{array}$ \\
\hline $\begin{array}{l}\text { Bed trook, et al., } \\
1979\end{array}$ & $\begin{array}{l}253 \text { (all le vels) } \\
\text { nonop in all } \\
\text { but } 171\end{array}$ & $\begin{array}{l}\text { retro case } \\
\text { series }\end{array}$ & III & $\begin{array}{l}13 \% \text { of Frankel if pts recovered } \\
\text { spontaneously }\end{array}$ \\
\hline $\begin{array}{l}\text { Donovan, et al., } \\
1987\end{array}$ & $\begin{array}{l}61 \text { (cer vical) } \\
43 \text { nonop }\end{array}$ & $\begin{array}{l}\text { retro case } \\
\text { series }\end{array}$ & III & $\begin{array}{l}31,43 \text { conser watively treated pts } \\
\text { im pro wed } \equiv 1 \text { Frankel }\end{array}$ \\
\hline Duh, et al., 1994 & $\begin{array}{l}487 \text { (all levels) } \\
189 \text { nonop }\end{array}$ & $\begin{array}{l}\text { pro series } \\
\text { w/controls; } \\
\text { nonran }\end{array}$ & II & $\begin{array}{l}\text { mean change score of } 13.2 \text { in } \\
\text { nonop pts }<\text { group undergoing } \\
\text { surgery win } 25 \mathrm{hrs} \text { (mean } \\
\text { change soore } 17.8 \text { ) }\end{array}$ \\
\hline Katoh, et al., 1996 & $\begin{array}{l}63 \text { (nnoomplete } \\
\text { cervical SCl) }\end{array}$ & $\begin{array}{l}\text { retro case } \\
\text { series }\end{array}$ & III & $\begin{array}{l}\text { neuro deterioration in } 663 \text {; } \\
\text { neuro im provement in } 44 \mathrm{pts}\end{array}$ \\
\hline
\end{tabular}

This approach has been advocated by those who adhere to the tenets of Sir Ludwig Guttmann, founder of the 
Stoke-Mandeville Hospital in England. Guttmann used postural techniques combined with bedrest to achieve reduction and spontaneous fusion of the spine. Operative approaches were rarely performed because of a higher incidence of neurological complications and impaired recovery after laminectomy procedures.[11,12,31,51,52] For example, Frankel, et al.,[48] reported on a cohort of 612 patients who suffered "closed spinal injuries" and who were treated by these techniques. Only four of these patients developed delayed instability and required operative fusion. However, detailed descriptions of the fractures and the criteria for determining spinal cord instability or failure of nonoperative management were not provided. Importantly, 29\% of Frankel A patients (with complete motor and sensory paralysis below the level of the injury) improved at least one grade during the course of their hospital stay.

In patients undergoing conservative therapy, the spontaneous improvement in neurological status has been replicated in several subsequent studies.[8,31,38,98,111,113] Accordingly, the comparative beneficial results of surgical treatment need to be weighed against the limited spontaneous recovery that occurs after SCI. Indeed, some authors have reported that neither spinal cord surgery or anatomical realignment of the spinal column improved neurological outcome in patients with acute SCI with the possible exception of those patients with bilateral locked facets.[35,55,70] To date, studies of nonoperative management are limited to noncontrolled, retrospective analyses of clinical databases and, accordingly, provide Class III evidence. Furthermore, it is now well recognized that laminectomy as the sole surgical technique is contraindicated in most cases of acute SCI because it usually fails to produce adequate decompression of the spinal cord and often causes spinal instability that itself can lead to neurological deterioration.

Although meticulous, conservative care remains the cornerstone of SCI management, modern surgical techniques have evolved considerably since the era of Guttmann. Furthermore, there are major limitations to using an exclusive policy of nonoperative management to treat patients with SCI. For example, there is evidence that neurological deterioration can occur in up to $10 \%$ of patients with incomplete cervical SCI who undergo an exclusively conservative management protocol.[59]

\section{Role of Decompressive Surgery in the Management of Acute SCI}

The evidence regarding the role of decompressive procedures in the management of SCI is summarized in Tables 3, 4, and 5 .

\section{TABLE 3}

EFFECT OF DECOMPRESSION IN PATIENTS WITH ACUTE SCl

\begin{tabular}{|c|c|c|c|c|c|}
\hline Authors \& Year & $\begin{array}{c}\text { No. of } \\
\text { Patierts } \\
\text { (level treated) }\end{array}$ & $\begin{array}{l}\text { Tirning of } \\
\text { Surgery }\end{array}$ & $\begin{array}{l}\text { Study } \\
\text { Design }\end{array}$ & $\begin{array}{l}\text { Class of } \\
\text { Evi- } \\
\text { dence }\end{array}$ & Resuls \\
\hline Larson, et al., 1976 & $\begin{array}{l}44 \text { (thoracic \& lum - } \\
\text { bar): }<1 \text { mk, } 8 \text { pts; } \\
>1 \text { mk, } 36 \text { pts }\end{array}$ & $\begin{array}{l}\text { early }<1 \text { mk } \\
\text { late }>1 w_{k}\end{array}$ & $\begin{array}{l}\text { retro case } \\
\text { series }\end{array}$ & III & $\begin{array}{l}\text { no difference in neurological re- } \\
\text { co'ery between "early" \& late } \\
\text { groups; preferable to wait }\end{array}$ \\
\hline $\begin{array}{l}\text { Maynard, et al., } \\
1979\end{array}$ & $\begin{array}{l}123 \text { (cervical); } 51 \\
\text { early; } 10 \text { late; } 62 \\
\text { nonop }\end{array}$ & $\begin{array}{l}\text { early }<4 \text { wks; } \\
\text { late }>4 \text { wks }\end{array}$ & $\begin{array}{l}\text { retro case } \\
\text { series }\end{array}$ & III & $\begin{array}{l}\text { surgery wd } 4 \text { whs not associated wh } \\
\text { im pro ved neurore co wery }\end{array}$ \\
\hline $\begin{array}{l}\text { Wugner \& Chehrazi, } \\
1982\end{array}$ & $\begin{array}{l}44 \text { (cervical): } 24 \text { op; } \\
20 \text { nonop }\end{array}$ & $\begin{array}{l}\text { early }<8 \mathrm{hrs} \\
\text { late } 9-48 \mathrm{hrs}\end{array}$ & $\begin{array}{l}\text { retro case } \\
\text { series }\end{array}$ & III & $\begin{array}{l}\text { decom wd } 8 \text { hrs not better than } 9- \\
48 \text { hrs; surgery does not im prove } \\
\text { recowery }\end{array}$ \\
\hline $\begin{array}{l}\text { Bohlman, et al., } \\
1985\end{array}$ & $218(T 1-10)$ & $\begin{array}{l}\text { most delajed } \\
(>1 \text { meek } \\
\text { post }-\mathrm{Scl})\end{array}$ & $\begin{array}{l}\text { retro case } \\
\text { series }\end{array}$ & III & $\begin{array}{l}\text { pt w' com plete injuriy reco vered } w / \\
\text { surgery; ant decom best for neu- } \\
\text { rore oo very in incom plete injuries }\end{array}$ \\
\hline Aebi, et al., 1986 & $\begin{array}{l}100 \text { (cervical): all } \\
\text { surgical }\end{array}$ & $\begin{array}{l}75 \% \text { reduced } \\
\text { wh } 6 \text { hrs }\end{array}$ & $\begin{array}{l}\text { retro case } \\
\text { series }\end{array}$ & III & $\begin{array}{l}\text { early reduc \& surgery im proved } \\
31 / 100 \text { cases }\end{array}$ \\
\hline $\begin{array}{l}\text { Benzel \& Larson, } \\
1986\end{array}$ & $\begin{array}{l}105 \text { (thoracic \& } \\
\text { lumber) }\end{array}$ & $\begin{array}{l}\text { all delayed } \\
\text { surgery (19- } \\
48 \text { days) }\end{array}$ & $\begin{array}{l}\text { retro case } \\
\text { series }\end{array}$ & III & $\begin{array}{l}\text { ant decom \& stabil resul ted in su- } \\
\text { perior neurorecowery to a nonop } \\
\text { approach or only statil }\end{array}$ \\
\hline Rental \& I arenn & 35 inoringl all & $1-4 \ln k=$ & vetrom inse & III & ant tamm imrense e naruse rant \\
\hline
\end{tabular}


Lיו1'

1986

Benzel \& Larson, 1987

Donovan, et al., 1987

Tator, et al., 1987

int berg \& Hauge 1988

wurphy, et al., 1990

udeinstiel, et al., 1990

Uholf, et al. 1991

Le'vi, et al., 1991

Krengel, et al., 1993

Duh, et al., 1994

Petitjean, et al., 1995

Uuaters, et al., 1996

Botel, et al., 1997

Wacoaro, et al., 1997

Vale, et al., 1997

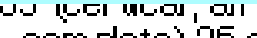

com plete) 25 ant; 10 post

99 (cervical)

61 (cervical): 18 op; 43 nonop

208 (all levels): 75

decom or reduced;

41 fusion; 92 nonop

30 (thoracic \& lum bar)

102 (cervical): 58 op;

44 nonop

90 (cer vical AS Śn

A \& B)

52 (cer vical bilat locked facets)

103 (cervical):

early 45; late 58

14 (T2-11 incomplete)

487 (all levels):

303 op; early 38

late 105

49 (thoracic): $65 \%$

associated $w /$

head injur'y

269 (all levels): 142

nonop; 127 op

255 (all levels): 178

op; $51.4 \%$ early,

$10.5 \%$ late

62 (cervical): early

34 ; late 28

77 (all levels): 58 op series

retro case III

series

wh 3 nos

wid 4 ws

retrocase III series

pro, nonran II

8 pts wi 24 hrs; retro case 2, 1-7 days; $20,>7$ days early $<2$ wks

6 hrs-60 days

(av 13 days)

40 pts reduced

$\leq 4$ hrs by trac-

tion; 23 op

$\leq 24$ hrs

early $<24 h r s$;

late $>24 \mathrm{hrs}$

retro case
series

$12 \mathrm{pts}<24 \mathrm{hrs}$

$1 \mathrm{pt} 36$ hrs

1 pt 5 days

early < 25hrs;

late $>200 \mathrm{hr}$

early av 12hrs;

late av 9 days

av $>14$ days

early $<24 \mathrm{hrs}$;

late $>2$ mks

early $<72 \mathrm{hrs}$;

late $>5$ days

$11 \mathrm{pts}<24 \mathrm{hrs}$; 13 24-72hrs; $34>72$ hrs

series

retrocase III

series

series

retro case

series

III

III

\section{retro case III} series; historical controls

pro, nonran II

pts lost to $\mathrm{FU}$

pro, nonran II recovery

surgery im pro wed neurofunction in incomplete SCl; no relationship between time to decom \& neurorecowery

no difference in outcome between op 8 nonop cases

surgery did not im prove neurorecovery or length of stay

retro case III

decom improved neurorecovery; 2 pts wicomplete SCl op wh $10 \mathrm{hrs}$ showed recovery

early surgery reduced $\mathrm{LOH} \&$ promoted earlier rehab

decom improved neuroreco very in

motor complete cervical SCl

early reduc of bilat locked facets resulted in neurorecovery in complete $\&$ incomplete $\mathrm{SCl}$

III early surgery may benefit overal management but not associated w/im proved neurorecower'y

early surgical reduc \& decom is safe $\&$ im proves neuro function;

? superior to historical controls

surgical decom $<25$ hrs or $>200$ hrs may be associated wh better recovery

spinal decom has no benefit in complete thoracic paraplegia.

no benefit to surgery, hovever, all pts underwent delayed treatment no neurorecovery in complete $\mathrm{SC}$; no dear relationstip of neurorecovery to timing

no difference in neurological out come no dear relationship between neuro outcome \& timing of surgery

" ant $=$ anterior; ASIA $=$ American Spinal Injury Association; av = average; FU = follow up; LOH = length of hospitalization; pos $=$ posterior $;$ reduc $=$ reduction; rehab $=$ rehatilitation; statil $=$ stabilization .

Most studies, with a few notable exceptions, are retrospective case series with historical controls (Class III evidence). From these studies, there is no clear consensus as to the appropriate timing of surgical intervention, nor is there compelling evidence that surgical decompression influences patient neurological outcome after SCI. For example, Aebi et al.,[1] Wiberg and Hauge,[109] Hadley, et al.,[53] and Wolf, et al.,[112] have advocated early spinal cord reduction procedures (4-10 hours) and operative fixation of spinal fractures associated with SCI. Suggestive evidence is presented in these studies that early decompressive surgery in selected patients may enhance neurological recovery. However, these studies were uncontrolled, and the beneficial effects need to be considered in the context of spontaneous recovery, which can occur in nonoperatively managed patients with SCI.[48,59]

The benefits of early surgical reduction procedures to treat spinal dislocations by either open or closed techniques are difficult to evaluate in the absence of randomization (Table 4).[1,26,32,49,107] Accounts of 
impressive neurological recovery in some patients who underwent early cervical decompression by traction must be considered anecdotal[26] (Table 4).

TABLE 4

EFFECT OF CLOSED REDUCTION ON NEUROLOGICAL RECOVERY AFTER ACUTE CERYGAL SC/A

\begin{tabular}{|c|c|c|c|c|c|}
\hline Authors \& Year & $\begin{array}{l}\text { No. of } \\
\text { Patierts }\end{array}$ & Intervertion & $\begin{array}{l}\text { Study } \\
\text { Design }\end{array}$ & $\begin{array}{l}\text { Class of } \\
\text { Evi- } \\
\text { dence }\end{array}$ & Resuls \\
\hline $\begin{array}{l}\text { Burke \& Berryman, } \\
1971\end{array}$ & 76 & $\begin{array}{l}\text { CR; } 50 \% \text { admit- } \\
\text { ted wd } 8 \text { hrs }\end{array}$ & $\begin{array}{l}\text { retro case } \\
\text { series }\end{array}$ & III & $\begin{array}{l}\text { early CR improwed neuro out- } \\
\text { come in incomplete } \mathrm{SC}\end{array}$ \\
\hline Dall, 1972 & 75 & timing of reduc & $\begin{array}{l}\text { retro case } \\
\text { series }\end{array}$ & III & $\begin{array}{l}\text { anatomical reduc of fracture- } \\
\text { disocations did not im prove } \\
\text { neuroreco very }\end{array}$ \\
\hline Harris, et al., 1980 & 145 & $\begin{array}{l}\text { protocol for trac- } \\
\text { tion NS }\end{array}$ & $\begin{array}{l}\text { retro case } \\
\text { series }\end{array}$ & III & $\begin{array}{l}\text { reduc of cervical disocations } \\
\text { did not improve neurooutcome }\end{array}$ \\
\hline Sonntag, 1981 & 15 & $\begin{array}{l}\text { CR in } 11 ; \text { open } \\
\text { in } 4\end{array}$ & $\begin{array}{l}\text { retro case } \\
\text { series }\end{array}$ & III & $\begin{array}{l}\text { transient root palsy in } 1 \text {; root } \\
\text { recowery in } 2\end{array}$ \\
\hline Aebi, et al., 1986 & 100 & $\begin{array}{l}75 \% \text { reduced wh } \\
6 \text { hrs }\end{array}$ & $\begin{array}{l}\text { retro case } \\
\text { series }\end{array}$ & III & $\begin{array}{l}\text { early reduc resulted in neuroim- } \\
\text { provement in } 31 / 100\end{array}$ \\
\hline $\begin{array}{l}\text { Erunette \& Rocks- } \\
\text { mold, } 1987\end{array}$ & 1 & $\begin{array}{l}\text { C3-4 reduced } \\
\text { by } 90 \text { mins }\end{array}$ & case report & III & $\begin{array}{l}\text { im pro uement from ASIA A to } \\
\text { ASIA E by rapid reduc of } \\
\text { C3-4 dislocation }\end{array}$ \\
\hline Star, et al., 1990 & 53 & $\begin{array}{l}3953 \text { required } \\
>50 \text { Ibs }\end{array}$ & $\begin{array}{l}\text { retro case } \\
\text { series }\end{array}$ & III & $\begin{array}{l}68 \% \text { of pts improved neurolo- } \\
\text { gically; no deterioration }\end{array}$ \\
\hline Hadley et al., 1992 & 54 & $\begin{array}{l}10 \text { reduced wh } \\
8 \mathrm{hrs}\end{array}$ & $\begin{array}{l}\text { retro case } \\
\text { series }\end{array}$ & III & $\begin{array}{l}\text { reduc wh } 8 \text { hrs in } 10 \text { cases } \\
\text { resulted in neuro im rovement }\end{array}$ \\
\hline Lee, et al., 1994 & 210 & $\begin{array}{l}\text { rapid traction } \\
\text { up to } 150 \text { Ibs }\end{array}$ & $\begin{array}{l}\text { retro case } \\
\text { series }\end{array}$ & III & $\begin{array}{l}\text { rapid realignment im proves } \\
\text { neuro outcome }\end{array}$ \\
\hline
\end{tabular}

Moreover, the authors of several studies have found no neurological benefit associated with reduction procedures, $[35,55,107]$ with the possible exception of patients with bilateral facet dislocation.[10] Burke and Berryman[28] have described 76 patients in whom unilateral or bilateral dislocations of the cervical spine were treated by performing closed reduction after induction of general anesthesia, often with manipulation; $50 \%$ of the patients were admitted to their center within 8 hours of injury. These authors concluded that early surgical reduction procedures improved the neurological recovery of patients with incomplete SCI.

Aebi, et al.,[1] have examined the records retrospectively of 100 patients with cervical spine injuries and attempted to relate neurological recovery to the timing of the reduction procedure by closed manual traction or open surgical reduction. A manual or surgical reduction procedure was performed within the first 6 hours postinjury in only $25 \%$ of the cases and within the first 24 hours in $57 \%$. Overall, $31 \%$ of the 100 patients recovered, and $75 \%$ of the recoveries were in patients in whom reduction was performed manually or surgically within the first 6 hours (Table 94). Cotler's group[32,73] studied the safety and effectiveness of early reduction procedures, and performed a prospective study of early reduction by traction in 24 patients. They found no neurological deterioration in any of the patients, most of whom underwent successful reduction procedures within 24 hours of injury, although the exact interval in hours between injury and intervention was not provided. All of the patients were awake during the procedure, although a muscle relaxant was administered to some patients.

In contrast to the aforementioned studies in which decompressive procedures were performed in the early stage after injury, Larson and coworkers[65] have advocated the surgery be performed a week or more after SCI to allow medical and neurological stabilization of the injured patient (Table 3). This remains the practice in many institutions, particularly in light of early reports, the results of which suggest an increased rate of medical complications when surgery is performed to early after injury ( $<5$ days after SCI).[71] Interestingly, 
a number of authors (summarized in Table 5) have documented recovery of neurological function after performing delayed decompressive surgery in the spinal cord (months to years)

postinjury.[9,15,17,19,24,65,101]

\begin{tabular}{|c|c|c|c|c|c|}
\hline \multicolumn{6}{|c|}{ TABLE 5} \\
\hline Authors \& Year & $\begin{array}{c}\text { No. of } \\
\text { Patierts } \\
\text { (level treated) }\end{array}$ & $\begin{array}{l}\text { Tirning of } \\
\text { Sugery }\end{array}$ & $\begin{array}{l}\text { Study } \\
\text { Design }\end{array}$ & $\begin{array}{l}\text { Class of } \\
\text { Evi- } \\
\text { dence }\end{array}$ & Resuls \\
\hline $\begin{array}{l}\text { Larson, et al., } \\
1976\end{array}$ & 25 (all levels) & $\begin{array}{l}\text { all }>4 \text { wks; } \\
15>6 \mathrm{mos}\end{array}$ & $\begin{array}{l}\text { retro case } \\
\text { series }\end{array}$ & III & $\begin{array}{l}\text { im pro ved neurorecovery wi th } \\
\text { surgery in complete and } \\
\text { incomplete Scl }\end{array}$ \\
\hline $\begin{array}{l}\text { Bohlman \& Free- } \\
\text { hafer, } 1979\end{array}$ & $\begin{array}{l}36 \text { (32 cer vical, } \\
4 \text { thoracolum- } \\
\text { bar) }\end{array}$ & av $22 \operatorname{mos}$ & $\begin{array}{l}\text { retro case } \\
\text { series }\end{array}$ & III & 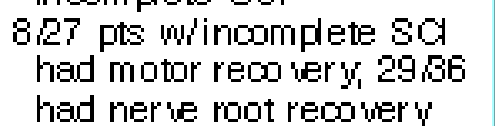 \\
\hline $\begin{array}{l}\text { Erodkey, et al., } \\
1980\end{array}$ & 83 & $m k s-4$ yrs & $\begin{array}{l}\text { retro case } \\
\text { seies }\end{array}$ & III & $\begin{array}{l}\text { im pro wed neurorecowery in } \\
\text { incomplete } \mathrm{SCl}\end{array}$ \\
\hline $\begin{array}{l}\text { Majman, et al., } \\
1984\end{array}$ & $\begin{array}{l}20 \text { (thoracolum- } \\
\text { ber) }\end{array}$ & $1 \mathrm{mo}-5 \mathrm{yrs}$ & $\begin{array}{l}\text { retro case } \\
\text { series }\end{array}$ & III & $\begin{array}{l}1720 \text { pts made neurore- } \\
\text { covery }\end{array}$ \\
\hline $\begin{array}{l}\text { Transfeldt, et al. } \\
1990\end{array}$ & $\begin{array}{l}49 \text { (thoracolum } \\
\text { (bar) }\end{array}$ & $>3 \mathrm{mos}$ & $\begin{array}{l}\text { retro case } \\
\text { series }\end{array}$ & III & $\begin{array}{l}46.5 \% \text { of incom plete } \mathrm{SCl} \\
\text { im proved neurologically }\end{array}$ \\
\hline $\begin{array}{l}\text { Anderson \& } \\
\text { Bohlman, } 1992\end{array}$ & $\begin{array}{l}51 \text { (cer vical: } \\
\text { motor com- } \\
\text { plete) }\end{array}$ & $\begin{array}{l}1 \text { mo-8 yrs } \\
\text { (av } 15 \text { mos) }\end{array}$ & $\begin{array}{l}\text { retro case } \\
\text { series }\end{array}$ & III & $\begin{array}{l}\text { im pro ved segm ental (1 or } 2 \\
\text { le vels) reco very in } 2551 \text {; } \\
\text { im pro ved distal cord func- } \\
\text { ton in } 1 \mathrm{pt}\end{array}$ \\
\hline $\begin{array}{l}\text { Bohlman, Ander- } \\
\text { son, } 1992\end{array}$ & $\begin{array}{l}58 \text { (cervical ; mo- } \\
\text { tor incom plete) }\end{array}$ & $\begin{array}{l}1 \text { mo-9yrs } \\
\text { (av } 13 \text { mos) }\end{array}$ & $\begin{array}{l}\text { retro case } \\
\text { series }\end{array}$ & III & $\begin{array}{l}\text { improved neurorecovery in } \\
46 \text { incom dete } \mathrm{SCl} \text { ots }\end{array}$ \\
\hline $\begin{array}{l}\text { Bohlman, et al., } \\
1994\end{array}$ & $\begin{array}{l}25 \text { (thoracolum- } \\
\text { bar) }\end{array}$ & av 4.5 yrs & $\begin{array}{l}\text { retro case } \\
\text { series }\end{array}$ & III & $\begin{array}{l}\text { 21/25 patients im proved } \\
\text { neurologically; proportion } \\
\text { incom plete undear }\end{array}$ \\
\hline
\end{tabular}

Although these studies were retrospective in design, the improvement in neurological function after delayed decompressive surgery in patients with cervical or thoracolumbar SCI whose recovery has plateaued is noteworthy; it suggests that compression of the cord is an important contributing cause of neurological dysfunction.

In our literature review we found five prospective, controlled studies of surgical decompression in acute spinal cord injury (Table 3). $[1,12,13,18,20,40,41,64,65,68,72,74,79,96,102-104,107-109,112]$ In a prospective, nonrandomized case control study of 208 patients with acute spinal cord or cauda equina injury, Tator and colleagues[96] compared the results of surgery (56\% of patients) with nonoperative management (44\% of patients). Operative management was associated with a lower overall mortality rate $(6.1 \%)$ than nonoperative treatment (15.2\%) despite a higher rate of thromboembolic complications in the surgical group. Overall, there was no difference between surgically and nonsurgically treated patients in length of stay or neurological recovery.

In an analysis of the NASCIS-2 database (Class II evidence), Duh, et al.,[41] reported that patients who underwent acute surgery ( $<25$ hours after injury) achieved statistically insignificant improvement (mean neurological change score of 17.8) when compared with a control cohort of patients who were treated nonoperatively (mean change score of 13.2). Interestingly, results of surgery were similar in the early $(<25$ hours postinjury) and delayed ( $>200$ hours postinjury) groups. In contrast, in a series of prospective studies Vale, et al.,[103] Vaccaro, et al.,[102] and Waters, et al.,[107] could not document a beneficial effect of decompressive surgery. It is noteworthy, however, that all patients underwent delayed operative management in the study by Waters, et al. Moreover, although the study by Vaccaro, et al., was a prospective randomized 
trial, 20 of the 62 patients were lost to follow up, and "early" surgery was defined as that performed within 72 hours after SCI. In view of the large number of patients lost to follow-up review, we have considered the study by Vaccaro, et al., to provide Class II evidence.

\section{THE EFFECT OF SURGERY ON THE COMPLICATION RATE AND THE LENGTH OF STAY AFTER SCI}

There has been controversy about whether surgery, especially early surgery, increases the rate of complications in patients with SCI. Many SCI patients with high cervical complete injuries or significant associated injuries to the limbs or viscera suffer critical illness due to either hemodynamic or respiratory difficulties. Early investigators such as Guttmann[51,52] and Bedbrook and Sekae[11] and, more recently, Wilmot and Hall[111] and Marshall, et al.,[71] have warned against surgery, (especially early surgery) in these critically ill patients. However, modern methods of respiratory and hemodynamic resuscitation $[60,67,82,103]$ have allowed these patients to undergo surgery with minimal differences in complication rates between operative and nonoperative cases.[96,111] Indeed, Wilberger's recent study[110] showed that those patients in whom operations were performed within the first 24 hours had a lower rate of complications than those who underwent surgery at later times. In a previously mentioned study from our center,[96] the only difference in morbidity rates between the surgical and nonsurgical cases was a slight increase in the incidence of deep venous thrombosis in the surgically treated group. The length of stay in the two groups did not differ.[96] In the randomized trial in which Vaccaro, et al.,[102] examined the timing of the surgery, there was no significant difference in length of acute postoperative intensive care stay or length of inpatient rehabilitation between the early and late groups. Thus, with respect to complications, there is no compelling evidence that early surgery increases the rate of complications.

\section{CONCLUSIONS}

There is strong experimental evidence from animal models to indicate that decompressive surgery in the spinal cord improves recovery after SCI. However, it is difficult to determine a time window for the effective application of surgical decompressive intervention in the clinical setting from these animal models. Results of these studies on secondary injury mechanisms including ischemia, free radical-mediated lipid peroxidation, and calcium-mediated cytotoxicity suggest that early intervention within hours after SCI is critical to attain a neuroprotective effect. Whether the same time window applies to surgical treatment is as yet unclear. To date, the clinical studies that have examined the role of decompressive surgery in the treatment of SCI are limited to Class II and Class III evidence, except for one study in which the timing of decompression was examined. Surgery remains a valid practice option, although there is no conclusive data showing a benefit over conservative management approaches. There is limited Class II evidence suggesting that either early ( $<25$ hours) or delayed ( $>200$ hours) surgical intervention is safe and equally effective. Clearly, to define better the role of surgery in the management of acute SCI, randomized controlled prospective trials are required.

\section{Acknowledgments}

The authors are grateful to Ms. Sandi Amaral and Ms. Maria Vespa for technical assistance.

\section{References}

1. Aebi M, Mohler J, Zach GA, et al: Indication, surgical technique, and results of 100 surgically-treated fractures and fracture-dislocations of the cervical spine. Clin Orthop 203:244-257, 1986

2. Agrawal SK, Fehlings MG: Mechanisms of secondary injury to spinal cord axons in vitro: role of Na+, 
$\mathrm{Na}(+)-\mathrm{K}(+)-\mathrm{ATPase}$, the $\mathrm{Na}(+)-\mathrm{H}+$ exchanger, and the $\mathrm{Na}(+)-\mathrm{Ca}++$ exchanger. J Neurosci 16:545-552, 1996

3. Agrawal SK, Fehlings MG: Role of NMDA and non-NMDA ionotopic glutamate receptors in traumatic spinal cord axonal injury. J Neurosci 17:1055-1063, 1997

4. Ahn JH, Ragnarsson KT, Gordon WA, et al: Current trends in stabilizing high thoracic and thoracolumbar spinal fractures. Arch Phys Med Rehab 65:366-369, 1984

5. Aki T, Toya S: Experimental study on changes of the spinal-evoked potential and circulatory dynamics following spinal cord compression and decompression. Spine 9:800-809, 1984

6. Allen AR: Surgery of experimental lesion of spinal cord equivalent to crush injury of fracture dislocation of spinal column. A preliminary report. JAMA 57:878-880, 1911

7. Anderson DK, Hall ED: Pathophysiology of spinal cord trauma. Ann Emerg Med 22:987-992, 1993

8. Anderson DK, Means ED, Waters TR: Spinal cord energy metabolism in normal and postlaminectomy cats. J Neurosurg 52:387-391, 1980

9. Anderson PA, Bohlman HH: Anterior decompression and arthrodesis of the cervical spine: long-term motor improvement. Part II--Improvement in complete traumatic quadriplegia. J Bone Joint Surg (Am) 74:683-692, 1992

10. Bedbrook GM: Spinal injuries with tetraplegia and paraplegia. J Bone Joint Surg (Br) 61:267-284, 1979 11. Bedbrook GM, Sakae T: A review of cervical spine injuries with neurological dysfunction. Paraplegia 20:321-333, 1982

12. Benzel EC, Larson SJ: Functional recovery after decompressive spine operation for cervical spine fractures. Neurosurgery 20:742-746, 1987

13. Benzel EC, Larson SJ: Recovery of nerve root function after complete quadriplegia from cervical spine fractures. Neurosurgery 19:809-812, 1986

14. Bohlman HH: Acute fractures and dislocations of the cervical spine. An analysis of three hundred hospitalized patients and review of the literature. J Bone Joint Surg (Am) 61:1119-1142, 1979

15. Bohlman HH, Anderson PA: Anterior decompression and arthrodesis of the cervical spine: long-term motor improvement. Part 1. Improvement in incomplete traumatic quadriparesis. J Bone Joint Surg (Am) 74:671-682, 1992

16. Bohlman HH, Bahniuk E, Raskulinecz G, et al: Mechanical factors affecting recovery from incomplete cervical spinal cord injury: a preliminary report. Johns Hopkins Med J 145:115-125, 1979

17. Bohlman HH, Freehafer A: Late anterior decompression of spinal cord injuries. J Bone Joint Surg (Am) 57:1025, 1979

18. Bohlman HH, Freehafer A, Dejak J: The results of treatment of acute injuries of the upper thoracic spine with paralysis. J Bone Joint Surg (Am) 67:360-369, 1985

19. Bohlman HH, Kirkpatrick JS, Delamarter RB, et al: Anterior decompression for late pain and paralysis after fractures of the thoracolumbar spine. Clin Orthop 300:24-29, 1994 
20. Botel V, Glaser E, Niedeggen A: The surgical treatment of acute spinal paralysed patients. Spinal Cord 35:420-428, 1997

21. Bracken MB, Holford TR: Effects of timing of methylprednisolone or naloxone administration on recovery of segmental and long-tract neurological function in NASCIS 2. J Neurosurg 79:500-507, 1993

22. Bracken MB, Shepard MJ, Collins WF, et al: A randomized controlled trial of methylprednisolone or naloxone in the treatment of acute spinal cord injury. Results of the Second National Acute Spinal Cord Injury Study. N Engl J Med 322:1405-1411, 1990

23. Bracken MB, Shepard MJ, Holford TR, et al: Administration of methylprednisolone for 24 or 48 hours or tirilazad mesylate for 48 hours in the treatment of acute spinal cord injury. Results of the Third National Acute Spinal Cord Injury Randomized Controlled Trial. JAMA 277:1597-1604, 1997

24. Brodkey JS, Miller CF Jr, Harmody RM: The syndrome of acute central cervical spinal cord injury revisited. Surg Neurol 14:251-257, 1980

25. Brodkey JS, Richards DE, Blasingame JP, et al: Reversible spinal cord trauma in cats. Additive effects of direct pressure and ischemia. J Neurosurg 37:591-593, 1972

26. Brunette DD, Rockswold GL: Neurologic recovery following rapid spinal realignment for complete cervical spinal cord injury. J Trauma 27:445-447, 1987

27. Bunge RP, Puckett WR, Becerra JL, et al: Observations on the pathology of human spinal cord injury. A review and classification of 22 new cases with details from a case of chronic cord compression with extensive demyelination. Adv Neurol 59:75-89, 1993

28. Burke DC, Berryman D: The place of closed manipulation in the management of flexion-rotation dislocations of the cervical spine. J Bone Joint Surg (Br) 53:165-182, 1971

29. Carlson GD, Minato Y, Okada A, et al: Early time-dependent decompression for spinal cord injury: vascular mechanisms of recovery. J Neurotrauma 14:951-962, 1997

30. Collins WF: A review and update of experimental and clinical studies of spinal cord injury. Paraplegia 21:204-219, 1983

31. Comarr AE, Kaufman AA: A Survey of the neurological results of 858 spinal cord injuries. A comparison of patients treated with and without laminectomy. J Neurosurg 13:95-106, 1956

32. Cotler JM, Herbison GJ, Nasuti JF, et al: Closed reduction of traumatic cervical spine dislocation using traction weights up to 140 pounds. Spine 18:386-390, 1993

33. Coyne T, Fehlings MG: Application of the Kaneda anterior spinal stabilization system, in Fessler RG, Haid RW (eds): Current Techniques in Spinal Stabilization. New York: McGraw-Hill, 1996

34. Croft TJ, Brodkey JS, Nulsen FE: Reversible spinal cord trauma: a model for electrical monitoring of spinal cord function. J Neurosurg 36:402-406, 1972

35. Dall DM: Injuries of the cervical spine. II. Does anatomical reduction of the bony injuries improve the prognosis for spinal cord recovery? S Afr Med J 46:1083-1090, 1972

36. Delamarter RB, Sherman J, Carr JB: Pathophysiology of spinal cord injury: recovery after immediate and delayed decompression. J Bone Joint Surg (Am) 77:1042-1049, 1995 
37. Demopoulos HB, Flamm ES, Pietronigro DD, et al: The free radical pathology and the microcirculation in the major central nervous system disorders. Acta Physiol Scand Suppl 492:91-119, 1980

38. Ditunno JF Jr, Sipski, ML, Posuniak EA, et al: Wrist extensor recovery in traumatic quadriplegia. Arch Phys Med Rehab 68:287-290, 1987

39. Dolan EJ, Tator CH, Endrenyi L: The value of decompression for acute experimental spinal cord compression injury. J Neurosurg 53:749-755, 1980

40. Donovan WH, Kopaniky D, Stolzmann E, et al: The neurological and skeletal outcome in patients with closed cervical spinal cord injury. J Neurosurg 66:690-694, 1987

41. Duh MS, Shepard MJ, Wilberger JE, et al: The effectiveness of surgery on the treatment of acute spinal cord injury and its relation to pharmacological treatment. Neurosurgery 35:240-249, 1994

42. Eismont FJ, Clifford S, Goldberg M, et al: Cervical sagittal spinal canal size in spine injury. Spine 9:663-666, 1984

43. Faden AI: Experimental neurobiology of central nervous system trauma. Crit Rev Neurobiol 7:175-186, 1993

44. Faden AI, Jacobs TP, Holaday JW: Comparison of early and late naloxone treatment in experimental spinal injury. Neurology 32:677-681, 1982

45. Faden AI, Jacobs TP, Smith MT: Evaluation of the calcium channel antagonist nimodipine in experimental spinal cord ischemia. J Neurosurg 60:796-799, 1984

46. Faden AI, Simon RP: A potential role for excitotoxins in the pathophysiology of spinal cord injury. Ann Neurol 23:623-626, 1988

47. Fehlings MG, Tator $\mathrm{CH}$ : A review of experimental models of acute spinal cord injury, in Illis L (ed): Spinal Cord Dysfunction. Oxford: Oxford University Press, 1988, pp 3-48

48. Frankel H, Hancock DO, Hyslop G, et al: The value of postural reduction in the initial management of closed injuries of the spine with paraplegia and tetraplegia. I. Paraplegia 7:179-192, 1969

49. Gillingham J: Early management of spinal cord trauma. J Neurosurg 44:766-767, 1976 (Letter)

50. Guha A, Tator CH, Endrenyi L, et al: Decompression of the spinal cord improves recovery after acute experimental spinal cord compression injury. Paraplegia 25:324-339, 1987

51. Guttmann L: Initial treatment of traumatic paraplegia and tetraplegia, in Harris P (ed): Spinal Injuries Symposium. Edinburgh: Morrison \& Gibb, Royal College of Surgeons, 1963, pp 80-92

52. Guttmann L: Spinal Cord Injuries. Comprehensive Management and Research, ed 2. Oxford: Blackwell, 1976

53. Hadley MN, Fitzpatrick BC, Sonntag VK, et al: Facet fracture-dislocation injuries of the cervical spine. Neurosurgery 30:661-666, 1992

54. Hall ED, Yonkers PA, Horan KL, et al: Correlation between attenuation of posttraumatic spinal cord ischemia and preservation of tissue vitamin E by the 21-aminosteroid U74006F: evidence for an in vivo antioxidant mechanism. J Neurotrauma 6:169-176, 1989 
55. Harris $\mathrm{P}$, Karmi MZ, McClemont E, et al: The prognosis of patients sustaining severe cervical spine injury (C2-C7 inclusive). Paraplegia 18:324-330, 1980

56. Hung TK, Albin MS, Brown TD, et al: Biomechanical responses to open experimental spinal cord injury. Surg Neurol 4:271-276, 1975

57. Hung TK, Chang GL, Chang JL, et al: Stress-strain relationship and neurological sequelae of uniaxial elongation of the spinal cord of cats. Surg Neurol 15:471-476, 1981

58. Kakulas BA: Pathology of spinal injuries. Cent Nerv Syst Trauma 1:117-129, 1984

59. Katoh S, el Masry WS, Jaffray D, et al: Neurologic outcome in conservatively treated patients with incomplete closed traumatic cervical spinal cord injuries. Spine 21:2345-2351, 1996

60. Kiss ZHT, Tator CH: Neurogenic shock, in Geller ER (ed): Shock and Resuscitation. New York: McGraw-Hill, 1993, pp 421-440

61. Kobrine AI, Evans DE, Rizzoli HV: Correlation of spinal cord blood flow and function in experimental compression. Surg Neurol 10:54-59, 1978

62. Kobrine AI, Evans DE, Rizzoli HV: Experimental acute balloon compression of the spinal cord. Factors affecting disappearance and return of the spinal evoked response. J Neurosurg 51:841-845, 1979

63. Kraus JF, Franti CE, Riggins RS, et al: Incidence of traumatic spinal cord lesions. J Chron Dis 28:471-492, 1975

64. Krengel WF III, Anderson PA, Henley MB: Early stabilization and decompression for incomplete paraplegia due to a thoracic-level spinal cord injury. Spine 18:2080-2087, 1993

65. Larson SJ, Holst RA, Hemmy DC, et al: Lateral extracavitary approach to traumatic lesions of the thoracic and lumbar spine. J Neurosurg 45:628-637, 1976

66. Lee AS, MacLean JC, Newton DA: Rapid traction for reduction of cervical spine dislocations. J Bone Joint Surg (Br) 76:352-356, 1994

67. Levi L, Wolf A, Belzberg H: Hemodynamic parameters in patients with acute cervical cord trauma: description, intervention, and prediction of outcome. Neurosurgery 33:1007-1017, 1993

68. Levi L, Wolf A, Rigamonti D, et al: Anterior decompression in cervical spine trauma: does the timing of surgery affect the outcome? Neurosurgery 29:216-222, 1991

69. Maiman DJ, Larson SJ, Benzel EC: Neurological improvement associated with late decompression of the thoracolumbar spinal cord. Neurosurgery 14:302-307, 1984

70. Marino RJ, Stineman MG: Functional assessment in spinal cord injury, in Apple DE (ed): Topics in Spinal Cord Injury Rehabilitation. Gaithersburg, MD: Aspen, 1996, Vol 1, pp 32-45

71. Marshall LF, Knowlton S, Garfin SR, et al: Deterioration following spinal cord injury. A multicenter study. J Neurosurg 66:400-404, 1987

72. Maynard F, Reynolds GG, Fountain S, et al: Neurological prognosis after traumatic quadriplegia. Three year experience of California Regional Spinal Cord Injury Care System. J Neurosurg 50:611-616, 1979

73. Miller LS, Cotler HB, De Lucia FA, et al: Biomechanical analysis of cervical distraction. Spine 
74. Murphy KP, Opitz JL, Cabanela ME, et al: Cervical fractures and spinal cord injury: outcome of surgical and nonsurgical management. Mayo Clin Proc 65:949-959, 1990

75. Noyes DH, Bresnahan JC: Correlation between spinal cord lesion volume and impact parameters. Proc Biophys Soc 33:H12, 1981 (Abstract)

76. Nystrom B, Berglund JE: Spinal cord restitution following compression injuries in rats. Acta Neurol Scand 78:467-472, 1988

77. Osterholm JL, Mathews GJ: Altered norepinephrine metabolism following experimental spinal cord injury. Part 1: Relationship to hemorrhagic necrosis and post-wounding neurological deficits. $\mathbf{J}$ Neurosurg 36:386-394, 1972

78. Panjabi MM: Experimental spinal cord trauma. A biomechanical viewpoint. Paraplegia 25:217-220, 1987

79. Petitjean ME, Pointillart V, Daverat P, et al: Administration of methylprednisolone or nimodipine or both versus placebo at the acute phase of spinal cord injury. J Neurotrauma 12:456, 1995 (Abstract)

80. Rivlin AS, Tator $\mathrm{CH}$ : Effect of duration of acute spinal cord compression in a new acute cord injury model in the rat. Surg Neurol 10:39-43, 1978

81. Rivlin AS, Tator CH: Objective clinical assessment of motor function after experimental spinal cord injury in the rat. J Neurosurg 47:577-581, 1977

82. Rosner MJ, Elias Z, Coley I: New principles of resuscitation for brain and spinal injury. North Carol Med J 45:703-708, 1984

83. Somerson SK, Stokes BT: Functional analysis of an electromechanical spinal cord injury device. Exp Neurol 96:82-96, 1987

84. Sonntag VK: Management of bilateral locked facets of the cervical spine. Neurosurgery 8:150-152, 1981

85. Star AM, Jones AA, Cotler JM, et al: Immediate closed reduction of cervical spine dislocations using traction. Spine 15:1068-1072, 1990

86. Stripling TE: The cost of economic consequences of traumatic spinal cord injury. Paraplegia News:50-54, August, 1990

87. Tarlov IM: Spinal Cord Compression: Mechanisms of Paralysis and Treatment. Springfield, Ill: Charles C Thomas, 1957

88. Tarlov IM: Spinal cord compression studies. III. Time limits for recovery after gradual compression in dogs. Arch Neurol Psychiatry 71:588-597, 1954

89. Tarlov IM: Spinal cord injuries--early treatment. Surg Clin North Am 35:591-607, 1955

90. Tarlov IM, Klinger H: Spinal cord compression studies. II. Time limits for recovery after acute compression in dogs. Arch Neurol Psychiatry 71:271-290, 1954

91. Tator CH: Epidemiology and general characteristics of the spinal cord injury patient, in Benzel EC, Tator 
CH (eds): Contemporary Management of Spinal Cord Injury. Neurosurgical Topics. Park Ridge, Ill: American Association of Neurological Surgeons, 1995, pp 9-13

92. Tator CH: Experimental and clinical studies of the pathophysiology and management of acute spinal cord injury. J Spinal Cord Med 19:206-214, 1996

93. Tator CH: Ischemia as a secondary neuronal injury, in Salzman SK, Faden AI (eds): Neurobiology of Central Nervous System Trauma. New York: Oxford University Press, 1994, pp 209-215

94. Tator CH: Review of experimental spinal cord injury with emphasis on the local and systemic circulatory effects. Neurochirurgie 37:291-302, 1991

95. Tator CH: Spine-spinal cord relationships in spinal cord trauma. Clin Neurosurg 30:479-494, 1983

96. Tator CH, Duncan EG, Edmonds VE, et al: Comparison of surgical and conservative management in 208 patients with acute spinal cord injury. Can J Neurol Sci 14:60-69, 1987

97. Tator CH, Duncan EG, Edmonds VE, et al: Complications and costs of management of acute spinal cord injury. Paraplegia 31:700-714, 1993

98. Tator CH, Duncan EG, Edmonds VE, et al: Neurological recovery, mortality and length of stay after acute spinal cord injury associated with changes in management. Paraplegia 33:254-262, 1995

99. Tator $\mathrm{CH}$, Fehlings MG: Review of the secondary injury theory of acute spinal cord trauma with empahsis on vascular mechanisms. J Neurosurg 75:15-26, 1991

100. Thienprasit P, Bantli H, Bloedel JR, et al: Effect of delayed local cooling on experimental spinal cord injury. J Neurosurg 42:150-154, 1975

101. Transfeldt EE, White D, Bradford DS, et al: Delayed anterior decompression in patients with spinal cord and cauda equina injuries of the thoracolumbar spine. Spine 15:953-957, 1990

102. Vaccaro AR, Daugherty RJ, Sheehan TP, et al: Neurologic outcome of early versus late surgery for cervical spinal cord injury. Spine 22:2609-2613, 1997

103. Vale FL, Burns J, Jackson AB, et al: Combined medical and surgical treatment after acute spinal cord injury: results of a prospective pilot study to assess the merits of aggressive medical resuscitation and blood pressure management. J Neurosurg 87:239-246, 1997

104. Wagner FC Jr, Chehrazi B: Early decompression and neurological outcome in acute cervical spinal cord injuries. J Neurosurg 56:699-705, 1982

105. Wagner FC Jr, Stewart WB: Effect of trauma dose on spinal cord edema. J Neurosurg 54:802-806, 1981

106. Wallace MC, Tator CH, Lewis AJ: Chronic regenerative changes in the spinal cord after cord compression injury in rats. Surg Neurol 27:209-219, 1987

107. Waters RL, Adkins RH, Yakura JS, et al: Effect of surgery on motor recovery following traumatic spinal cord injury. Spinal Cord 34:188-192, 1996

108. Weinshel SS, Maiman DJ, Baek P, et al: Neurologic recovery in quadriplegia following operative treatment. J Spinal Disord 3:244-249, 1990 
109. Wiberg J, Hauge HN: Neurological outcome after surgery for thoracic and lumbar spine injuries. Acta Neurochir 91:106-112, 1988

110. Wilberger JE: Diagnosis and management of spinal cord trauma. J Neurotrauma 8 (Suppl 1):S21-S30, 1991

111. Wilmot CB, Hall KM: Evaluation of the acute management of tetraplegia: conservative versus surgical treatment. Paraplegia 24:148-153, 1986

112. Wolf A, Levi L, Mirvis S, et al: Operative management of bilateral facet dislocation. J Neurosurg 75:883-890, 1991

113. Wu L, Marino RT, Herbison GJ, et al: Recovery of zero grade muscles in the zone of partial preservation in motor complete quadriplegia. Arch Phys Med Rehab 73:40-43, 1992

114. Young W: The post-injury responses in trauma and ischemia: secondary injury or protective mechanisms? Cent Nerv Syst Trauma 4:27-51, 1987

115. Young W: Secondary CNS injury. J Neurotrauma 5:219-221, 1988

116. Young W, Huang PP, Kume-Kick J: Cellular, ionic and biomolecular mechanisms of the injury process, in Benzel EC, Tator CH (eds): Contemporary Management of Spinal Cord Injury. Neurosurgical Topics. Park Ridge, Ill: American Association of Neurological Surgeons, 1995, pp 27-42

117. Young W, Koreh I: Potassium and calcium changes in injured spinal cords. Brain Res 365:42-53, 1986

118. Zhang Y, Hillered L, Olsson Y, et al: Time course of energy perturbation after compression trauma to the spinal cord: an experimental study in the rat using microdialysis. Surg Neurol 39:297-304, 1993

Manuscript received November 24, 1998.

Accepted in final form December 18, 1998.

Dr. Fehlings is supported by a Ministry of Health Career Scientist Award. This work was supported by the Samuel Lunenfeld Foundation, Canadian Paraplegic Association (Ontario Branch), the Canadian Spinal Research Organization and the Joint Section of Neurotrauma and Critical Care, and the Joint Section of Disorders of the Spine and Peripheral Nerves.

Address reprint requests to: Michael G. Fehlings, M.D., Division of Neurosurgery, The Toronto Hospital Western Division, 399 Bathurst Street, McLaughlin Pavilion 2-435, Toronto, Ontario, Canada, M5T 2S8. email: mfehlings@torhosp.toronto.on.ca. 